\title{
The changing of oral argumentation process of grade XI students through Socratic dialogue
}

\author{
I W Pangestika ${ }^{1, a)}$, M Ramli ${ }^{2, b)}$ and Nurmiyati ${ }^{3, c)}$ \\ ${ }^{1,2,3}$ Department of Biology Education, Faculty of Teacher Training and Education \\ Sebelas Maret University, Jl. Ir. Sutami No. 36 A Kentingan Surakarta \\ E-mail: \\ intanwidya@student.uns.ac.id \\ mramlim@staff.uns.ac.id \\ nurmiyati@staff.uns.ac.id
}

\begin{abstract}
Arguments are one of the important purposes in the modern era of learning because it is the basic step to promote student's critical thinking process and science literacy. Argumentation process can be trained through interactive dialogue that provides opportunities for students to argue. This research aims to change oral argumentation process in biology class of high school through the application of the Socratic Dialogue. The participants were students of grade XI science in one high school located in Surakarta, selected purposively. A classroom action research was done collaboratively between student teacher, lecturers, and teacher, follow the spiral cycles of research by Stephen Kemmis. During the implementation of research, the audio recorder has prepared to record the dialogue and arguments of the students. Next, data recorded that was converted to a dialogue transcript analyzed qualitatively using the Toulmin Argumentation Patterns (TAP). Another data source is teacher's reflective diaries that contained notes during the learning process. The result shows that student's oral argumentation process found were only claiming supported by weak warrants. Implementation of the Socratic Dialogue brings positive changes in oral argumentation process of the students, proven by the complete argumentation pattern include claims, data, warrants, backings, and rebuttals at the end of the research cycle. A classroom action research which is developed collaboratively and implement interactive dialogue also inquiry learning is highly recommended to change student's oral argumentation process.
\end{abstract}

\section{Introduction}

Argumentation is not a new thing, since some great thinkers, such as Socrates, Plato, and Aristotle, have taught us how to argue cleverly and wisely since long time ago. Argumentation also plays important roles in determining how strong science is constructed. Scientists have used their arguments to construct theories, models, and explanations of the natural phenomenon [1].

It is exactly true, that argumentation is one of the important learning objects in this modern era. It serves as the basis of nurturing student's scientific literature and critical thinking. Javier et al. (2015) suggest that argumentation is a dialogic process and fundamental instrument to construct students' more meaningful understanding, therefore its existence in the learning process is absolutely essential [2]. Bricker \& Bell (2008) also mention that argumentation is the core of science learning since the objectives of science education are mastering science concepts and involving students in a scientific discourse as well [3]. 
The success of argumentation process is one of the objectives of learning. The training of students' argumentation skills in the class is expected to be able to create an open-minded learning atmosphere, in which students try to find science concepts through the presentation of arguments and sharing creative ideas, as well as doing discussion. Doing argumentation will also affect positively on students' attitudes and behaviors; such as students will appreciate others' opinions, accept critics sincerely, and always develop a positive thinking to any critics or disapprovals.

The learning situation which can strongly engage students to argue has not been well addressed in the biology classes of grade XI of one senior high school in Surakarta, a small city in Central Java Province in Indonesia, where I did my teaching practicum during my pre-service teacher training. The learning activities which practiced by the assigned teacher usually had not adequately facilitated students to do argumentation. In fact, students usually jot down teacher's explanation of the learned topic and sometimes respond to the teacher's questions with short answers, which are not argumentative statements.

Other factors will contribute to poor argumentation process in the biology class are the lack of discussion activities and the assessment model that teacher often used. The number of discussion activity is considered insufficient when one period of a certain topic (usually 3 to 6 meetings) is taught. For example, the teacher only provided once discussion for students, and the rest was focused on teacher's expository. Assigned teacher argued that lecturing is more effective to transfer concepts to students, and she believes that there will be fewer misconceptions among students. Moreover, the type of instrument commonly used for assessing students' achievement is a series of multiple or short answer questions with mostly requiring students to memorize the concepts. The assessment in which students are trained to think argumentatively, such as a high order thinking skills (HOTS) test, are not common.

Various actions are argued as attempts to improve oral argumentation process in the class. Interactive learning using dialogue can be the one approach to engage students to deliver arguments in the class. Another possible action is promoting more discussions to give students a wider chance to state their opinion argumentatively. During the discussion activities, the teacher should always give instructions to students to do correct argumentation. Finally, to promote writing argumentation of students, the assessment with higher-order questions should be prepared.

In the case of my class, I believe that creating an interactive learning through dialogue is the most effective way, since learning through dialogue does not take much time like discussion does. A dialogue selected for improving students' argumentation process is different from the regular daily conversation. The dialogue should involve critical and meaningful questions which can stimulate students to deliver arguments correctly, and master the learning concepts as well. The teacher is required to apply sequence dialogues from the general context to specific context which will foster students to think systematically, find a sort of solution for giving problems, and finally 
express their strong arguments. The model of dialogue which meets the criteria is Socratic Dialogue.

Socratic Dialogue is a dialogue method originated from the habits of Old Greek philosopher, Socrates (470 BC - 399 BC) who was fond of making detailed conversation with his interlocutors. He posted general initial questions and later moved to more specific questions until no answers or consensus were able to be provided. This is supported by a statement of Stylinger \& Overstreet (2014) that Socratic Dialogue is a method used to develop self-understanding on certain information by making use of dialogue. Participants in the dialogue are directed to dig more definitions of complex ideas [4].

Socratic Dialogue offers many benefits for a learning process. It trains dialogic skills which are important for students' interpersonal competence. At the same time, Socratic Dialogue also provides a space for students to learn dialogue with and from one another [5]. This dialogue contains normative aspects for students to make a contribution to rational values. Moreover, students can follow a learning process to clarify a problem which has been considered right all this time [6].

Socratic Dialogue is a dialogue conducted by students guided by the teacher as the facilitator, with the purpose of achieving a consensus to answer fundamental questions based on real-life examples [7]. The implementation of Socratic Dialogue in learning includes six procedural stages, namely: (1) deciding topic of discussion (subject matter); (2) developing two or three questions which will be used in the dialogue; (3) observing students when cognitive conflict and concept contradiction happen; (4) requisitioning things which can potentially emerge cognitive conflicts; (5) continuing interview (question and answer) which points to cognitive conflict resolution with more in-depth analyses; and (6) drawing final conclusion based on cognitive conflict resolution [8].

The implementation of Socratic Dialogue is expected to be able to transform students' argumentation processes to be more desirable. The form of argumentation which will become the focus of the research is dialectical or dialogic argumentation. Dialectical argumentation is an argument which involves the expression of different perspectives during discussion or debate activities. This type of argument is often used in debate and consideration of problems which have not reached any consensus [9].

According to Driver et al. (2000), argumentation is a scientific practice in scientific discourse used by scientists to develop knowledge through evaluating scientific claims, enforcing pieces of evidence, and explaining alternative reasons [10]. Argumentation is an important element in science learning experience and becomes vital in a science learning process [3]. Argumentation skill is significant to develop a learning process since it is promising to change students' conceptual understanding of biology, and the topics on biology will facilitate students to learn to find and apply scientific methods [11]

The measurement to assess the argumentative skills of students which mostly used by educational researchers, follow Toulmin's Argument Pattern (TAP). On the basis of Toulmin's perspectives, elements of an argument involve claims, data, warrants, 
backing, qualifiers, and rebuttals. The claim is a conclusion which will be drawn; data are interesting facts to support claims; $a$ warrant is reason which supports the relationship between data and claims; backing is theoretical assumption which guarantees warrant; qualifier is limitation of a claim; and rebuttal is an argument which tries to oppose elements of an argument [12]. Toulmin's Argument Pattern is presented in Figure 1.

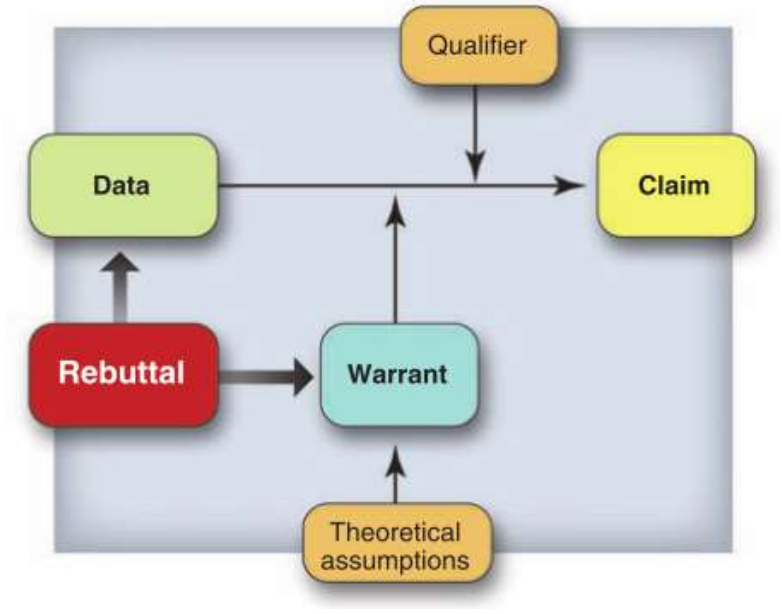

Figure 1.Toulmin's Argument Pattern entails six elements of an argumentation, comprising: claims; data; warrants; backing (theoretical assumptions); mualifierc. and rehuttals [137

Toulmin's Argument Pattern based on the assumption of the presence of the complete elements of an argument demonstrates better quality of an argument. An argument containing claims, data, and warrants are still considered as a simple argument, while an argument with backing, qualifiers, and rebuttals to support data and warrants is considered more complex and sophisticated [14]

The assumption of Toulmin's Argument Pattern is supported by Erduran et al. (2004) work, in indicating that first level of argumentation includes arguments with claims or counterclaims, second level argumentation is claims accompanied with data, warrants, or backing, third level argumentation is addition of weak rebuttals on the second level argumentation, fourth level argumentation occurs when students add one clear rebuttal on the second level, and fifth or the highest level argumentation is when students provide clear and relevant multiple-rebuttal [15].

Based on the fact found in my class, I decided to apply the Socratic Dialog to solve the problems of students in arguing scientifically through the iterative cycles of action research. I worked collaboratively with the assigned biology teacher to do this action research. 


\section{Method}

The Classroom Action Research (CAR) was carried out from September to November 2016 to improve the argumentation process on the four topics of Plant Tissues, Animal Tissues, Human Skeletal System, and the Cardiovascular System. My target were students of the first class of Grade XI who opted mathematics and natural science as their advanced course. All twenty students of eight boys and twelve girls agreed to participate in this action research.

The lesson plan was designed collaboratively by assigned teacher, trainee student, and student supervisor. The trainee student was the one who did the instructional learning during this action research. She had accomplished courses in education in three years in Faculty of Teacher Training and Education. The supervising teacher had taught more than 15 years as a biology teacher.

The CAR followed a cycle of action research proposed by Kemmis, McTaggart, \& Nixon (2014) including planning transformation, implementing the plan in the certain action, observing the action, and reformulating plans for the following action. The steps later become self-reflection to form a spiral cycle [16].

The steps implemented in the research procedures included planning, acting, and reflecting. Planning comprised preparation of teaching instruments, such as Lesson Plans (containing scenario of Socratic Dialogue), and media or tools of learning, and recording all dialogues. The acting was carried out by applying Socratic Dialogue combined with a certain teaching model in learning activities. Reflecting was done by jotting down all in sight of role teacher in the form of a reflective diary.

During the learning process, dialogues in the class were recorded to be further analyzed to investigate students' pattern of argumentation. The audio recording was later converted into the transcript of the dialogue. Reflective diary written by the teacher was further used to make learning, reflection and arrange Lesson Plans in the subsequent cycle.

The data obtained include dialogue transcript and teacher's reflective diary, and they were later analyzed qualitatively. A qualitative description on dialogue transcript was conducted by making a certain interpretation of each part of the dialogue. The interpretation of dialogue described argumentation components accomplished by students, and the reflective diary noted all activities occurred during the learning process. The reflective diary was also utilized as a reference for the detail process happened during the action.

We planned to have four cycles of action since we believed that at the end of the action, students will implement an adequate argumentation process, where students are able to deliver their arguments by following Toulmin's Argumentation Pattern which covers elements including claims, data, warrants, backings, qualifiers, and rebuttals. This method is in line with Heng (2014) who said that the presence of complete TPA's elements demonstrates better quality of an argument [14].

\section{Result and Discussion}

Prior to the corrective action, I did a series of observations of the classes taught by assigned teacher. It gave the overview on students' everyday learning situations. During two periods of 
the topic of Plant and Animal Tissues, the teacher had demonstrated a conventional learning in which teacher was the only source of knowledge. The strategy of teaching was mostly delivered lectures within two or three pauses allow students to ask questions.

It indicated that when learned about Plant Tissues, students tended to passively participate in. Instead of doing complete argumentation (data, warrants, and rebuttals), they often claimed simply to response teacher's questions. However, students' argumentation on the subsequent learning about Animal Tissues seemed better, although it had not yet been perfected. Some students who were at first quiet and passive started to make arguments after they had been appointed by teachers to do so. Students made brief claims and few weak warrants, or even no warrants.

I have been assigned to teach the next topic, i.e. Human Skeletal System. Then, I started to implement Socratic Dialogue in this cycle, called cycle 1. The practical laboratory work-based learning was carried out and followed the steps of inquiry laboratory on the topic of Components of Skeletal System (Skeleton, Joints, and Muscles). I began the lesson by asking some initial questions about the fact of movement of human or animal body followed the steps of Socratic Dialog. I demonstrated some movements of human, and subsequently asked students to do an exploration activity of human movements in groups. The movements that they found were discussed in a group to answer the question, why human body can move actively. At the end of learning, students did a presentation. Through these activities, the patterns of students' argumentation were found. The student's argumentation found in the dialogue that discusses the differences between movement performed by plants, animals, and humans. The dialogue then conical on thermal to the components that help humans to move around, such as skeleton, joints, and muscles. Table 1 illustrates an example of Socratic Dialogue implemented in cycle 1.

Table 1. Example of Socratic Dialogue in the Cycle 1

\begin{tabular}{|c|c|}
\hline \multicolumn{2}{|r|}{ Dialogues } \\
\hline Teacher & "Why is plant movement called passive movement?" \\
\hline Student 19 & "Because plants do not need energy." \\
\hline Teacher & $\begin{array}{l}\text { :"Is it correct that plants do not need energy?" "What is the result of } \\
\text { photosynthesis for?" }\end{array}$ \\
\hline Student 10 & "The result of photosynthesis is for food storage." \\
\hline Teacher & $\begin{array}{l}\text { :"Energy resulted from photosynthesis is used for metabolism, } \\
\text { movement, and food storage." }\end{array}$ \\
\hline & "Why is plant movement called passive movement?" \\
\hline Student 8 & "Because plants do not move from place to place." \\
\hline Student 11 & $\begin{array}{l}\text { : "Because plants do not move independently. The wind, for } \\
\text { example, contributes to plant movement." }\end{array}$ \\
\hline Student 6 & $\begin{array}{l}\text { : "Plants movement is passive in nature because plants make less } \\
\text { movement and do not move from place to place." }\end{array}$ \\
\hline Teacher & $\begin{array}{l}\text { : "Absolutely. Plants movement is called passive movement since } \\
\text { plants have limited mobility and do not move from place to place." }\end{array}$ \\
\hline $\begin{array}{l}\text { Interpretation } \\
\text { of Dialogue }\end{array}$ & $\begin{array}{l}\text { The dialogue has represented argumentation process. At first, } \\
\text { students merely made claims of animal/ human active movement } \\
\text { and plant passive movement. After some questions had been } \\
\text { addressed, students included warrants in their arguments in the } \\
\text { forms of sentences emphasizing that passive movement is caused } \\
\text { by limited mobility and is only found in plants. Students provided } \\
\text { warrants after the teacher had given feedback to their arguments. }\end{array}$ \\
\hline
\end{tabular}


Eight parts of the dialogue, with a different interpretation, were found in the cycle. Overall, students were found to have better argumentation skills in cycle 1. Prior to the first stage, students merely made claims and few weak warrants, or even no warrants. In cycle 1 , however, students were able to make claims supported by data, warrants, or backings, although the teacher had to give feedback first. This indicates better improvement, but I wrote in my reflective diary to highlight that students' argumentation process had not yet been adequately since the rebuttals had not been performed.

Students' argumentation process did not show significant improvement until cycle 2. The significant improvement is made in the next cycle when students can provide simple rebuttals in cycle 3. In this cycle, I focused on a Socratic Dialogue to learn about the Structure of Muscle. I checked the prior knowledge of students first, then started to ask some inquiry questions. At the end of a learning process, together with students, we stated the concepts that we have learned. The dialogue that appears in the Table 2 discusses about the abnormalities that can occur in muscles, one of them is muscle hypertrophy that cause muscle mass are larger than normal size. I give question to students about the harmfulness of muscle hypertrophy, then some students mutually arguing about these topics by presenting evidence and rebuttals. The implementation of Socratic Dialogue in cycle 3 led students to the invention of the concepts of various topics (Table 2).

Table 2. Example of Socratic Dialogue in the Cycle 3

\begin{tabular}{|c|c|}
\hline \multicolumn{2}{|r|}{ Dialogues } \\
\hline Student 12 & : "Miss, is muscle hypertrophy in bodybuilders harmful?" \\
\hline Teacher & : "Can anyone of you answer the question?" \\
\hline Student 5 & : "Yes, it is. It belongs to abnormality." \\
\hline Teacher & : "In your opinion, why is it harmful?" \\
\hline Student 5 & $\begin{array}{l}\text { "Because the muscle size is greater than normal size. It causes } \\
\text { damage to the muscle." }\end{array}$ \\
\hline Teacher & $\begin{array}{l}\text { : "Muscle will not get damaged, but rather it experiences muscle } \\
\text { fatigue due to vigorous exercise, for exact." } \\
\text { "Is there any other answers?" }\end{array}$ \\
\hline Student & : (Quiet) \\
\hline $\begin{array}{l}\text { Interpretation } \\
\text { of Dialogue }\end{array}$ & $\begin{array}{l}\text { The dialogue brings students to argue. Student } 5 \text { included } \\
\text { rebuttals on questions regarding the danger of muscle } \\
\text { hypertrophy asked by Student } 12 \text {, but they were supported by } \\
\text { weak warrants. The teacher helped Student } 5 \text { by giving further } \\
\text { dialogue. As a result, the student provided sufficiently logic } \\
\text { warrants. }\end{array}$ \\
\hline
\end{tabular}

Table 2 outlines the students' argumentation process which indicates a significant improvement. In the previous cycles, students made claims, data, warrants, and backing. In cycle 3, however, students were able to make arguments in the forms of claims supported by warrants. In addition, they also provided rebuttals, the highest level of the argumentation's pattern. Students had the courage to deliver counter arguments in 
communicative ways to oppose ideas developed in another argument. Due to simple rebuttals students made, I decided in my reflective diary to conduct further cycle with the purpose of strengthening elements of students' arguments, including rebuttals.

The research revealed that optimal transformation of the argumentation process happened in cycle 5. Meanwhile, cycle 4 did not show significant changes. Discovery learning was applied on Abnormalities of the Cardiovascular System. I routinely checked the prior knowledge of students, then provided an example of analysis of the topic. I conducted group discussions to ask students to make poster regarding Abnormalities of Cardiovascular System, and finally asked groups to present their poster. The poster contains points that discuss about the causes, cures, and ways to cope a cardiovascular disease. Students can debate and expressed arguments with talk about the content of the posters that have been made. Socratic Dialogue was implemented during teacher's guidance and direction in cycle 5. The example of Socratic Dialogue in cycle 5 can be seen in Table 3 .

Table 3. Example of Socratic Dialogue in the Cycle 5

\begin{tabular}{|c|c|}
\hline \multicolumn{2}{|r|}{ Dialogues } \\
\hline Teacher & $\begin{array}{l}\text { : "Thanks for the presentation. Is there any question or } \\
\text { feedback for our friends in the Group 1?" }\end{array}$ \\
\hline Student 11 & $\begin{array}{l}\text { :You stated that coronary heart disease is caused by high } \\
\text { concentration of LDL. What is LDL?" }\end{array}$ \\
\hline Student 9 & $\begin{array}{l}\text { : "LDL is bad fat. High concentration of bad fat in our body } \\
\text { can clog artery coronary, leading to coronary heart disease." }\end{array}$ \\
\hline Student 11 & "What is bad fat like?" \\
\hline Student 9 & : "It is fat contained in unhealthy food like junk food." \\
\hline Teacher & $\begin{array}{l}\text { : "What do you think, Student } 11 \text { ? Is the answer acceptable? I } \\
\text { will explain LDL further." }\end{array}$ \\
\hline Student 11 & : "Yes, it is, Miss." \\
\hline $\begin{array}{l}\text { Interpretation } \\
\text { of Dialogue }\end{array}$ & $\begin{array}{l}\text { The dialogue indicated that students were able to think } \\
\text { independently. The teacher facilitated them to discuss. In } \\
\text { this cycle, Student } 11 \text { made a rebuttal on the Group 1's } \\
\text { presentation. Student } 9 \text { as a member of the Group } 1 \\
\text { provided good claims and warrants to answer the question. } \\
\text { When Student } 11 \text { gave a further rebuttal, Student } 9 \text { was able } \\
\text { to give backing to the argument. This indicates an } \\
\text { improvement in student's argumentation process. }\end{array}$ \\
\hline
\end{tabular}

Cycle 5 gave opportunities for students to make arguments independently; the teacher served as a facilitator. Students' argumentation in initial learning comprised such elements as claims, warrants, and backing, leading to argumentation. Claims were made during group discussion and warrants were made during teacher's guidance. Such pattern of argumentation was considered sufficient to bring to argumentation process. Group 2, 3, and 4 only gave warrants during the question and answer session, contributing to a little possibility to lead to argumentation. On the contrary, Group 1 
made a pattern of argumentation consisting of warrants, backings, and rebuttals, allowing to lead to argumentation.

The delivered contents of the students' arguments were more substantial and critical in cycle 5 of the research. Students presented better rebuttals since they were supported by relevant shreds of evidence and reasons. Students were able to think more independently due to the teacher's guidance and direction.

The classroom action research in an attempt of the change of argumentation process was carried out until cycle 5. Students were considered to be able to make an optimal transformation of argumentation. The fact is indicated from the transformation of simple warrants in a pretreatment stage to be a pattern of argumentation consisting of claims, data, warrants, backing, and rebuttals with a teacher's guidance.

Students' argumentation process showed positive changes and involved the gradual improvement of the patterns. Cycle 1 and cycle 2 did not show a significant change in argumentation, but a better improvement was found. During the two cycles, most of the students made claims. They waited for teacher's feedback to asked supporting sentences to deliver data and warrants. Students focus on making claims/ statements since they present as the basis of problem-solving [17].

Students did not always make claims with warrants and backing until the second cycle. Instead of including warrants and backing in their claims, students deliver warrants when the teacher gave further dialogue to ask for clarification since they believed that all of the students in the class had gotten an understanding of their claims. Berland \& Hammer's (2012) research results indicate that senior high school students tend to give warrants when interlocutors show the lack of understanding support [18].

Students' oral argumentation process experiences a gradual improvement in cycle 3 . Students delivered claims with warrants. At the end of the cycle, they have recognized rebuttals. The first rebuttals were delivered in a simple way. They did not include supporting reasons unless the teacher asked to do so. Kuhn \& Udell (2007) explain that senior high school students are able to oppose an argument with their counter arguments if they are asked to do so, but they rarely do it spontaneously [19]. According to Bathgate, et al. (2015), students avoid making rebuttals considering their risks in discussion activities, particularly argumentation. They are concerned that their counter arguments can bring about negative impacts in their social life [20].

The argumentation process of the targeted students was adequate in cycle 5 of the research. It is revealed by the pattern of argumentation following Toulmin's Argument Pattern comprising claims, data, warrants, backing, and rebuttals. Argumentation in this cycle is considered better than a pretreatment stage when students argued with either claims only or claims with weak warrants.

The present classroom action research reveals that Socratic Dialogue allows to gradually train students' argumentation process. Students at first made claims during the dialogue, but in the subsequent cycles, they were required to support their claims with evidence and supporting reasons, such as data, warrants, and backings. The implementation of the dialogue in learning enables students to get used to learning to 
invent concepts and to lead to debates and presentation of counter arguments, a part of the elements of an argument (rebuttals). The Socratic Dialogue indirectly leads students to each element of an argument, starting form claims to rebuttals to generate optimal argumentation.

At the end of the research, students were able to make arguments using Toulmin's Argumentation Pattern comprising claims, data, warrants, backings, and rebuttals with a teacher's guidance. This is in line with the statement of Wortel \& Verweij (2008) that Socratic Dialogue provides insights into the participant's ways of thinking, the values that they hold, and the preconceived opinions they may have [6].

\section{Conclusion and Suggestion}

The results of the research indicate the changes of the students' argumentation process after the implementation of Socratic Dialogue. Students' argumentation which at first included claims and weak warrants is improved to be optimal in the end of cycles. Learning activities applied in this action research were able to facilitate students to explore their abilities to construct new knowledge. It is the main point too, which should be combined with the Socratic Dialog. Students will not able to argue if the concepts that they owned are not sufficient. Therefore, it can be recommended that the first step to be improved is correcting the wrong concepts of students through the argumentation process.

\section{References}

[1] Erduran S, Ardac D, and Yakmaci-Guzel B 2006 Eurasia Journal of Mathematics,Science, and Technology Education Learning to Teach argumentation: case studies of pre-service secondary science teachers 22

[2] Javier F, Ortega R., Eugenio O, and Alzate T 2015 Educ. Pesqui., São Paulo A model for teaching argumentation in science class 413 629-643

[3] Bricker L A and Bell P 2008 Science Education Conceptualizations of argumentation from science studies and the learning sciences and their implications for the practices of science education $92 \quad 3 \quad 473-498$ https://doi.org/10.1002/sce.20278

[4] Stylinger M E and Overstreet J 2014 Voices from the Middle Strengthening argumentative writing with speaking and listening (socratic) circles 22 158-62

[5] Knezic D, Wubbels T, Elbers E, and Hajer M 2010 Teaching and Teacher Education The socratic dialogue in teacher education 264 1104-1111 https://doi.org/10.1016/j.tate.2009.11.006

[6] Wortel E and Verweij D 2008 Practical Philosophy Inquiry, criticism and reasonableness: socratic dialogue as a research method? 92 54-72

[7] Knezic D, Elbers E, Wubbels T, and Hajer M 2013 The Modern Language Journal Teacher's Education in Socratic Dialogue: Some effects on teacher learner interaction 972 490-505 DOI: 10.1111/j. 1540-4781.2013.12014.x https://doi.org/10.1111/j.1540-4781.2013.12014.x

[8] Nurjannah A dan Suprapto N 2014 Jurnal Inovasi Pendidikan Fisika (JIPF) Pengaruh penerapan pembelajaran socrates terhadap keterampilan berpikir 
kritis dalam pembelajaran fisika pada materi hukum Newton 32 20-26

[9] Tippett C 2009 Journal of Elementary Science Education Argumentation: the language of science $21117-25$

[10] McNeill K L 2014 Journal of Research in Science Teaching Elementary Student's views of explanation, argumentation, and evidence, and their abilities to construct arguments 48 793-823 https://doi.org/10.1002/tea.20430

[11] Ramli M, Rakhmawati E, Hendarto P, and Winarni 2017Journal of Physics: Conf. Series Process of argumentation in high school biology class: a qualitative $\begin{array}{llll}\text { analysis } & \mathbf{8 1 2} & 1-7 & \text { (doi:10.1088/1742-6596/812/1/012007) }\end{array}$ https://doi.org/10.1088/17426596/365/1/011001

[12] Aufschnaiter C. Von, Erduran S, Osborne J, and Simon S 2008 Journal of Research in Science Teaching Arguing to learn and learning to argue: case studies of how students' argumentation relates to their scientific knowledge 1-4 DOI: $10.1002 /$ tea.20213. https://doi.org/10.1002/tea.20213

[13] Osborne J 2010 Science Arguing to learn in science: the role of collaborative, critical discourse 328 463-466 DOI: 10.1126/science.1183944

[14] Heng L L 2014 International Education Studies Individual versus group argumentation: student's performance in a malaysian context. 77 109-124

[15] Lee H S, Pallant A, Pryputniewicz S, and Liu O L 2013 Paper Presented at the Annual Meeting of the National Association for Research in Science Teaching, Rio Grande, Puerto Rico Measuring students' scientific argumentation associated with uncertain current science 1-47

[16] Kemmis S, McTaggart R, and Nixon R 2014 The Action Research Planner (ISBN 978-9) (Singapore: Springer)

[17] Pritasari A C, Dwiastuti S, and Probosari R M 2016 Jurnal Pendidikan Biologi Peningkatan kemampuan argumentasi melalui penerapan model problem based learning pada siswa kelas X MIA 1 SMA Batik 2 Surakarta tahun pelajaran $2014 / 201581-7$

[18] Berland L K and Hammer D 2012 Journal of Research in Science Teaching $\begin{array}{llllll}\text { Framing for } & \text { scientific } & \text { argumentation } & 49 & 1 & 68-94\end{array}$ https://doi.org/10.1002/tea.20446

[19] Kuhn D and Udell W 2007 Psychology Press Coordinating own and other

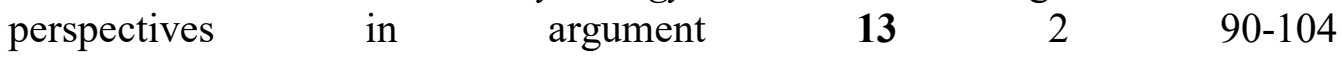
https://doi.org/10.1080/13546780600625447

[20] Bathgate M, Crowell A, Schunn C and Dorph R 2015 International Journal of Science Education The learning benefits of being willing and able to engage in scientific argumentation $37-41$ https://doi.org/10.1080/09500693.2015.1045958 